This is a pre-print version of an article published in Ageing \& Society, doi: 10.1017/S0144686X16000209

\title{
Being lonely later in life: a qualitative study among Albanians and Moroccans in Italy
}

\author{
ERALBA CELA \\ Polytechnic University of Marche, Department of Economics and Social Sciences, Ancona, \\ Italy \\ TINEKE FOKKEMA \\ Netherlands Interdisciplinary Demographic Institute (NIDI-KNAW), University of Groningen \\ and Erasmus University Rotterdam, The Hague, The Netherlands
}

\begin{abstract}
This study focuses on the social wellbeing of older migrants in Italy, an important yet neglected topic in the Italian political and scholarly debate. Knowledge about the lived experience of loneliness and its perceived causes was gathered by means of 34 in-depth interviews with Albanian and Moroccan migrants aged 50 and older living in the Marche region. Our findings show that the participants are surrounded by family and are largely satisfied with the contact they have with relatives; this protects them from social isolation but not from loneliness. Although they rarely express this to their spouse and friends (men) or their children (men and women), feelings of loneliness are widely experienced among the participants. The root of their loneliness largely relates to a lack of meaningful relationships with non-related age peers - having a chat, remembering old times, socializing with others when family members are busy, talking about intimate matters they cannot or will not share with relatives - which supports the argument of loneliness scholars that different types of relationships serve different functions and fulfil different needs. Having more contact with people outside the family circle, especially with co-ethnic peers, could reduce these feelings of loneliness substantially, but factors such as discrimination and lack of Italian language proficiency, free time, financial resources and nearby contact facilities are hindrances. These factors offer clues for public loneliness interventions.
\end{abstract}

KEY WORDS - ageing migrants, first and zero generation, loneliness, peers, Italy, Albanians, Moroccans 


\section{Introduction}

Since the mid-1970s, Italy has witnessed rising numbers of migrants due to its economic development, a lack of immigration legislation, and the restrictive immigration policies adopted by the traditional immigration countries of Europe (Bonifazzi et al. 2009; King, Lazaridis and Tsardanidis 2000). The migration phenomenon in Italy has been characterised by flows of different intensity and composition over time, resulting in a wide array of nationalities (198 on 1 January 2015; ISTAT, Italian Institute of Statistics). In the last ten years, migration has become a structural element of Italian society and the migrant population has more than tripled, going from 1.3 million individuals reported in the 2001 census to 5 million on 1 January 2015. At present, the migrant population in Italy represents 8.2 per cent of the total population (ISTAT). While in northwest Europe migrants are concentrated in the largest cities, in Italy their distribution is more widespread because of migrants' preference for small-size cities, reflecting the same pattern of settlement as the native population (Balbo 2015).

Due to the rather recent migration phenomenon, the current age structure of the migrant population in Italy is relatively young, with only 9.5 per cent aged 55 and older and 2.7 per cent over 65 (ISTAT). According to ISTAT projections, however, the proportion of $65+$ migrants will rapidly increase, reaching 8.7 per cent in 2031 and about 19 per cent by 2051 . The older migrant population consists mainly of two groups: the first generation - the pioneers, usually males, who came to Italy at a young age to work and were followed by their spouses; and the so-called zero generation (Nedelcu 2009) - migrants' ascendants who emigrated to Italy at a relatively old age as a family strategy to exchange both downward and upward intergenerational support, i.e. to look after their grandchildren in Italy and to be close to their children, who can take care of them if their health deteriorates (King et al. 2014).

Despite the increasing number of older migrants, they are virtually absent in Italian public debate and research on migration. The attention of politicians and scholars has so far focused primarily on regulation of migration flows and border controls (Finotelli and Sciortino 2009; Solé 2004; Triandafyllidou and Ambrosini 2011); progressively on integration aspects (Caponio 2010; Cela, Fokkema and Ambrosetti 2013; Fokkema and de Haas 2011); and in the last decade on the emergence of the second generation (Barban and White 2011; Dalla Zuanna, Farina and Strozza 2009; Gabrielli, Paterno and Dalla Zuanna 2013 ) and the 'badanti' (caregivers) phenomenon, migrant women privately hired to take care of the native elderly at home (Boccagni and Ambrosini 2012; Chiatti et al. 2013; Di Rosa et al. 2012; Pasquinelli and Rusmini 2010). Another strand of research examines the extent to which migration can mitigate the ongoing ageing process in the presence of a lowest-low fertility context. ${ }^{\mathrm{i}}$

One of the main reasons for the lack of interest in older migrants is probably the general persistent tendency of Italian policymakers to perceive migration as a temporary phenomenon (Ambrosetti, Cela and Fokkema 2013). And yet, although migrants often cherish the wish to eventually go home, and unemployment and retirement may trigger return migration (Percival 2013; Warnes and Williams 2006), some European studies show that several factors (like better social and economic security, proximity to children and grandchildren, and access to good health facilities) restrain most of them from doing so (Bolzman, Fibbi and Vial 2006; Ganga 2006). Rather, they adopt pendular strategies, travelling back and forth and spending several months per year in their origin country while keeping their official residence in the destination country (Bolzman, Fibbi and Vial 2001, 2006; de Coulon and Wolff 2010; de Haas and Fokkema 2010; Fokkema, Cela and Witter 2016).

Another reason for the negligence towards older migrants in the political and scholarly debate could be the fact that older migrants in Italy are not yet in need of care, given their relatively young age and married status - and if they do need care it is often assumed to be 
given by their children or other relatives, which is in line with the Italian family-oriented welfare regime. Despite older migrants' preference for informal care over formal care (Bolzman et al. 2004; Ebrahim 1996), there is increased empirical evidence for Europe that receiving support from family members (mainly daughters and daughters-in-law) is less guaranteed than it would have been in their home country, due to changed circumstances in terms of willingness, time and traditional views of younger generations about intergenerational support (Arjouch 2005; de Valk and Schans 2008; King et al. 2014; Lan 2002).

More attention to the social wellbeing of older migrants is warranted though. Previous research in other European countries shows that older migrant groups include some of the most deprived and socially isolated and excluded individuals (Warnes and Williams 2006), like older Spanish and Italian migrants in Switzerland (Bolzman, Fibi and Vial 2006), ageing migrants in Portugal (Ciobanu 2012), and first-generation migrants in the Netherlands (den Draak and de Klerk 2011). More generally speaking, the double condition of being a migrant as well as older increases the risk of vulnerability in terms of poor economic and health status and low civic participation, with adverse social wellbeing outcomes like loneliness (Fokkema and Naderi 2013; Victor, Burholt and Martin 2012; Warnes and Williams 2006). Although similar research is lacking for older migrants in Italy, there is no reason to believe that their social wellbeing outcomes are more positive. On the contrary, Italian integration policies are characterised by some specificities that might rather reinforce older migrants' vulnerability. Firstly, instead of a national, overarching model of integration, integration policies are decentralized at the regional and local levels. Consequently, integration measures are fragmented and their implementation varies by region and municipality, depending on the socioeconomic conditions and the willingness to invest in activities for migrants (Balbo 2015; Caneva 2014; Caponio 2002, 2006). Secondly, Italian integration policies are focused mainly on economic integration, whereas cultural and social policies remain marginal (Caponio and Zincone 2011). National funds allocated to regions to expand and improve social services have been drastically reduced recently, and those for the social inclusion of migrants have even been eliminated or were never implemented (Caneva 2014). Thirdly, Italian local authorities and non-state actors who initiate or financially support social integration activities for migrants pay particular attention to women, minors and the second generation (Caneva 2014). Older migrants are seldom their target population; apart from some local initiatives for linguistic mediation in public healthcare facilities, to the best of our knowledge, culturally sensitive healthcare services and older migrant-specific social activities are lacking.

The current study seeks to explore the lived experiences and perceived causes of loneliness amongst older migrants in Italy. To this end, in-depth semi-structured interviews were conducted in the Marche region between January 2013 and January 2014 with 34 migrants aged 50 and older of two nationalities: Albanian and Moroccan, representing the largest non-EU communities both in the Marche region and in Italy (ISTAT 2013). Where relevant, differences between the two migrant types (first versus zero generation) and across gender and origin (Albanians versus Moroccans) are noted.

The remainder of the paper is structured as follows. The first part introduces the concept of loneliness, along with its main causes. The second part presents the research methodology used to collect and analyse the data. The third part moves on to the results, discussing the lived experiences and perceived causes of loneliness among ageing Albanian and Moroccan migrants in Italy. The final part is reserved for future research directions and practical and policy implications of our findings. 


\section{Loneliness}

Loneliness is 'the unpleasant experience that occurs when a person's network of social relations is deficient in some important way, either quantitatively or qualitatively' (Perlman and Peplau, 1981:38). Although loneliness and social isolation are closely linked and often used interchangeably, theoretically speaking they are different concepts (Cornwell and Waite 2009; de Jong Gierveld, van Tilburg and Dykstra 2006). Social isolation refers to the lack of ties with others, a situation that can be objectively measured. Loneliness, on the other hand, is a subjective negative assessment of one's relationships, because of a mismatch between a person's actual and desired quality and number of social relations (de Jong Gierveld 1984). Accordingly, some people are socially isolated but do not feel lonely; they choose to be alone and do not want others 'crowding' them. Others can feel lonely despite living with other people and having a large social network, because something fundamental is missing in their social contacts (e.g. absence of a partner or another close relationship, lack of intimacy within their relationships, less contact than preferred with specific persons; Dykstra 2009).

Three groups of potential causal factors of loneliness are usually identified: interindividual, intra-individual and societal. The first group, inter-individual causes, relates to transitions in life that may reduce the number and/or variety of meaningful relationships or limit the opportunities to maintain relationships. Such transitions are, for example, the event of migration (Routasalo and Pitkala 2003), institutionalisation (Prieto-Flores et al. 2011; Routasalo and Pitkala 2003), unemployment (Lauder, Sharkey and Mummery 2004), divorce (Dykstra and Fokkema 2007), death of loved ones (Dykstra and de Jong Gierveld 2004; Jylhä 2004; Routasalo and Pitkala 2003; Victor et al. 2005), and health deterioration (Jylhä 2004; Routasalo and Pitkala 2003; Victor et al. 2005). Research on loneliness among older adults shows that widowhood is a key risk factor for loneliness; in a good relationship the partner is usually considered as the primary source of support and intimacy, therefore widowhood becomes the waiting room of loneliness (de Jong Gierveld et al. 2009). Poor health, which increases dependency on others and restricts social participation and outdoor social activities, is another important factor among older adults that often generates feelings of loneliness (de Jong Gierveld, van Tilburg and Dykstra 2006; Fokkema, de Jong Gierveld and Dykstra 2012; Fokkema and Naderi 2013; Hawkley et al. 2008).

The second set of factors, intra-individual causes, refer to a lack of personal social resources such as poor social skills, shyness and low self-esteem (Guiaux 2010; Peplau, Miceli and Morasch 1982; Wittenberg and Reis 1986) that affect and impair people's ability to make friends and have rewarding social relations. Another important factor in this group is people's socioeconomic status: resources like income, employment and education are important determinants of heterogeneous social relations. A high socioeconomic status provides a wide array of opportunities to meet others, while insufficient or lacking resources narrow one's social network and reduce the possibilities of social interaction (Fokkema, de Jong Gierveld and Dykstra 2012; Fokkema and Naderi 2013; Hawkley et al. 2008; Rao, Warburton and Bartlett 2006).

Thirdly, in addition to individual factors societal ones can trigger feelings of loneliness. In this respect, one may think of discrimination and stigmatisation towards specific groups (Kuyper and Fokkema 2010; Nachega et al. 2012), which may negatively affect a person's sense of integration and belonging to society and generate high levels of social isolation, feelings of rejection and loneliness. Moreover, there is an increased likelihood of loneliness when living in deprived and poor neighbourhoods with few or poor-quality social activities and transportation means, and where multiple conflicts may arise between and within generations and ethnic groups (Scharf, Phillipson and Smith 2005; Scharf and de Jong Gierveld 2008). 
In this paper we explore the lived loneliness experiences and the relevance and specifics of the three listed groups of causal factors of loneliness for Albanian and Moroccan older migrants in Italy according to three dimensions: nationality, gender and generation.

\section{Data and methods}

\section{Study context}

This study draws on interviews with 19 Albanian and 15 Moroccan migrants aged 50 and older, conducted between 2013 and 2014. The research context - the Marche region - is located in central Italy, between the Apennine Mountains and the Adriatic Sea. The Marche region faces a greying and declining population because of an above-average life expectancy and a high internal and international migration of natives that started in the 1950s (Moretti 2011). The region has one of the highest percentages of older people in Italy: 22.4 per cent aged 65 and older against 20.1 per cent at the national level (Moretti 2011). It is further characterised by a low level of urbanisation. Apart from Ancona, the capital city of the Marche region with a population of around 100,000, the other urban centres have populations between 35,000 and 45,000 inhabitants (Moretti and Cela 2008; Morettini and Socci 2012) while no less than 134 of the 246 Marche municipalities have less than 3,000 inhabitants (ISTAT). The region's population density is 165 persons per $\mathrm{km}^{2}$ compared with the national average of 201 persons per $\mathrm{km}^{2}$ (ISTAT).

Marche represents an interesting case study, as it witnessed a substantial influx of migrants in the last two decades (ISTAT), triggered by regional economic growth in the small- and medium-sized industrial sectors (e.g. leather, textiles, furniture and household appliances), tourism and fishing. ISTAT estimated that on 1 January 2015, 145,130 foreignborn migrants lived in Marche, representing 9.4 per cent of the total population of the region and about 3 per cent of the foreign population residing in Italy. Contrary to the super-diversity (Vertovec 2006) of big urban areas and gateway cities like Rome, Milan and Turin, the smaller cities of the Marche region are characterized by a limited range of nationalities (Morettini and Socci 2012). As small- and medium-sized enterprises are scattered throughout the region, there is a likewise widespread settlement pattern of both native and migrant populations (Moretti and Cela 2008). Under such conditions, it is more difficult for migrants to create ethnic communities, associations of ethnic signature or other types of formal social support (Balbo 2015). Furthermore, two-thirds of the region is hilly and mountainous. There is only one motorway and poor connection between municipalities because of insufficient public transport, especially between the numerous small towns of the hinterland. This means that even short distances become huge, time-consuming or even unbridgeable for those who cannot drive or do not have a car (Morettini and Socci 2012).

\section{Research instrument}

A semi-structured interview guide was designed to obtain information about the lived experiences and perceived causes of loneliness. The research instrument can be seen as divided into two parts, although a firm line between them is impossible to draw. The first part of the interviews served as a prolonged, warm-up introduction and dealt with the topics of situation prior to emigration, integration into the host society, transnational ties with the home country, and future migration plans. It consisted of a number of broad questions that were sufficiently open to allow participants to reflect freely on their migration experiences and perceptions of social relationships. The second part of the interviews builds explicitly upon the topic of loneliness, where most questions were formulated following prior theoretical knowledge of the concept and potential causal factors of loneliness (see Section 2). Given the sensitive nature of the topic of loneliness (de Jong Gierveld 1998; Lau and Gruen 1992), it 
was addressed only in the latter stage of the interview. By talking first about migration experiences and links to the country of origin we sought to put the participants at ease and create a relaxed atmosphere. We pilot-tested the research instrument with six participants, which did not lead to wording and structure changes in the interview guide - on the contrary, it served as a verification that topics related to the home country helped to create a relaxed interviewing environment and questions about loneliness serve as a natural continuation of migration narratives. Indeed, the topic of loneliness arose several times during their narrative of migration experience, integration and other related topics.

\section{Data collection}

We started to recruit participants through purposive sampling, utilising key informants such as representatives of associations, language mediators, teachers at Arabic schools, and workers in the social and healthcare sectors. By turning to various key informants we sought to recruit a heterogeneous group of interviewees in terms of age, gender, educational level, place of origin (urban versus rural) and type of migrant (both zero- and first-generation migrants). The purposive sampling procedure was complemented by a snowballing approach in order to identify more participants. The interviewing process stopped when data saturation was achieved, in other words when no new information was provided by the interviewees.

We interviewed participants in both private and public spaces, like home, the university and public cafes. The in-depth face-to-face interviews were conducted in Albanian, Arabic and/or Italian, depending on the participant's preference, and lasted from two to three hours. Thanks to an Albanian background and fluency in both Albanian and Italian, the first author was able to switch between the two languages as needed. For those Moroccan participants who were not fluent in Italian, the first author received assistance from a second-generation bilingual Moroccan student. We were aware that introducing a third party to the interviews might have an impact on the information collected and reported. Nonetheless, given the sensitive topic under study it was important to gain the participants' trust, and speaking the same language and sharing common culture with the interviewees was an important tool in establishing such a rapport. In order to avoid data collection bias, the student assistant was carefully instructed on how to conduct the interviews. All interviews were audio-taped, following participants' consent.

\section{Participants' background}

Our participants were relatively young (see Table 1), with a mean age of 64 for Albanians and 59 for Moroccans. More than half of the Albanians $(n=10)$ and only four Moroccans were female. In terms of their reason to migrate, two-third of the participants were either labour migrants $(n=19)$ or female followers $(n=4)$. More zero-generation Albanians than zerogeneration Moroccans ( $n=9$ against $n=2)$ were interviewed, reflecting the higher prevalence of the zero-generation phenomenon in the Albanian community: data on staying permits issued to migrants who arrived in 2011 shows that 9.6 per cent of Moroccans were over age 55, as compared with 11.6 per cent of the Albanians. Relatively more Moroccans than Albanians had the Italian citizenship (6 out of 15 against 4 out of 19), resulting from their longer migration history; with the exception of one Albanian participant with a short permit of stay, ${ }^{i}$ all other interviewees had a long staying permit. ${ }^{i i i}$ As one could expect, compared with the labour migrants, zero-generation migrants were the more recent (year of arrival range: 19982012 against 1984-1999) and, on average, older (mean age: 70 against 58). The overwhelming majority of the participants $(n=29)$ were still married. With only one exception, all the participants had one or more children living in Italy, with 2.6 as mean number of children for Albanians and 3.6 for Moroccans. At least 28 participants had no children living in their home country. The Albanian interviewees were higher educated than the Moroccans: 14 out of the 
19 Albanians had completed secondary or higher education, compared to 8 out of the 15 Moroccans, while on the other side of the spectrum only one of the Albanian and four of the Moroccan participants did not finish primary school. Most of the participants $(n=24)$ perceived their health as good; only seven participants rated their health as poor even though they were not in need of care and were still active caregivers just like the other participants. Given the exploratory nature of our study and its qualitative design, the sample is not representative of the older Albanian and Moroccan migrant population living in Italy. Accordingly, the findings cannot be generalised beyond the study sample.

\section{$<$ Insert Table 1 about here >}

\section{Data analysis}

The data analysis follows a number of subsequent steps and can be best described as thematic (Guest, MacQueen and Namey 2012). First, the interviews were transcribed verbatim by the first author or the student assistant; the interviews in Italian and Albanian were translated into English by the first author. Aware of the bias that might be potentially introduced by the translation (Temple and Young 2004) and in order to assure cultural appropriateness in the use of words and linguistic expressions, the first author was supported by a bilingual translator (Arabic-English) for the few interviews carried out in Arabic by the student assistant. This process was further validated through continued discussion with the student assistant.

Second, using Atlas.ti the interviews were coded by means of both inductive and deductive codes. By means of deduction we coded segments of the participants' narratives that reflected the theoretical framework of the concept and causes of loneliness described in Section 2. By means of induction, on the other hand, we coded parts of the interviews that pertained to loneliness but were unique to the migrants' personal stories and experiences. To check reliability and ensure the validity of codes, both authors coded each narrative separately and engaged in a continuous discussion until consensus was reached. The coding process was interactive, going back and forth through the data. The codes were subsequently collapsed into conceptual categories. The interviews were re-read several times to get a good understanding and identify recurrent categories. As a final step, the categories were grouped into themes. The themes that emerged from this analytical procedure are used as a framework that underpins the results section.

\section{Results}

\section{Narratives of loneliness}

In the first part of the interview, when asking about their migration experience, integration, links with the origin country and other related topics, the participants often spoke about loneliness. Especially the first stage after migration was extremely difficult in many respects. The interviewees not only went through a cultural shock (Oberg 1960) when faced with a new society with distinct cultural norms and values and a different language, but also lost daily contact with stay-behinds, resulting in strong feelings of loneliness and related psychological and emotional problems like homesickness, feelings of sadness and depression: When I arrived [in Italy] I cried for six months, I had no one with whom to have a coffee as I was used to, I didn't even want to get out of bed, I felt lonely and depressed. In Albania I always had people around me with whom I organized the day, in Italy I prepared the children to go to school, my husband went to work and I was left home alone. All I had in Albania, relationships, the pleasure of being with family and friends, here it was all gone, I was sad (A1f8). ${ }^{\text {iv }}$ Unlike the female first generation and the zero generation, who migrated in order to 
join their husbands or children in Italy, first-generation males often migrated alone. Some of them, particularly those who had entered Italy illegally, experienced anxieties, insecurities and complete social isolation in the first period: I arrived in Italy alone with a tourist visa. It was not easy to legalise my position, I spent a year and a half up in the hills surrounding the city without going once to the city centre because the police would stop everybody to check documents, and if you didn't have documents, according to the laws at that time you were sent back home and weren't allowed to return for 10 years. It was a very tough life full of fear and anxiety. When the police came I ran through the fields and hid, and practically lived in the dark without going out, except for shopping or school. Those were difficult times, also psychologically (A1m3).

The rough psychological edges of the migration move have mostly disappeared over the years. Interviewees have adjusted more to their new environment, or at least there appears to be a certain level of resignation or acceptance of the negative sides of migration as well as of the fact that their destiny is in Italy. Yet feelings of loneliness do not seem to have faded. Expressions of present feelings of loneliness such as 'I felt lonely, I feel lonely' (M1m1), 'Loneliness will be our lifelong companion in this foreign land' (A1m4) and 'My broken life between the two sea shores evokes my loneliness' (A0f19) are evident in many of the narratives. To some extent, job and care responsibilities push loneliness from the foreground to the background of a migrant's life: I feel a bit lonely, but I'm with my family. And then nostalgia for my country or my old friends no longer takes first place. My job is now my preoccupation. There's no time to think so much about loneliness (M1m2). But on days of no responsibilities, feelings of loneliness become more prominent: I felt lonely many times and still I feel lonely often. It happens to me when I have some free time, then I think about my life and the people I care about, who are far away from me, in Albania (A0f19).

In the second part of the interview, when asking directly about their present feelings of loneliness, a gender difference emerged. While our female participants had no problems talking directly about their feelings of loneliness, their male counterparts were more hesitant to straightforwardly admit that they (sometimes) feel lonely. This gender difference seems to be the result of gendered norms and expectations of showing and sharing feelings and emotions. In general, our male participants narrated that they do not discuss feelings of loneliness with either their friends or their wives, often out of shame and fear of being seen as weak. This is exemplified by the following quotes: Usually talking about it [loneliness] doesn't happen, it is an intimate topic. This does not mean that we [men] aren't lonely, we keep it inside, we just don't say it (A1m4); Everybody says they're fine. It [talking about feelings of loneliness] seems like a weakness (M1m11); They [men] don't wash their dirty linen in public (A1m6); Women are different, they talk a lot about everything, they don't need to be ashamed (A0m7). Our female participants, on the other hand, mentioned that they are less afraid of speaking in public about their loneliness, and often do so with other women outside the family circle: Among women we often talk about loneliness, especially as we feel alone, because our husbands are too busy thinking about themselves (M0f5). Moreover, they openly showed their emotions during the interview; some even cried. There is one aspect in which male and female participants seem not to differ: they rarely speak with their children about their feelings of loneliness, mainly in order to avoid worrying their children. This is echoed by an Albanian man and woman: We are very open in my family and talk about various things, but not about loneliness. I don't want to worry them [children] (A1m1); I will never talk about my loneliness with my children. I can't reverse the roles, not that much. I will speak about my feelings with a friend who can understand and advise me. If I talked to my children, they would only be concerned, nothing else (A0f16). 


\section{Perceived causes of loneliness}

What explains the present feelings of loneliness among our older Albanian and Moroccan migrants? A general pattern emerging from our analysis of the data is that a deficit of social relationships beyond the family setting and in particular the lack of meaningful relationships with co-ethnic peers in the host country seems to generate feelings of loneliness among the participants. All interviewees are surrounded by family and are largely satisfied with the frequency and quality of contact they have with family members, which insures they are not socially isolated. The only exception is a 60-year-old single Moroccan man who distances himself from others, which results in anxious feelings about lack of connectedness or communality with people and fear of being 'always alone, as if the train had passed me by' (M1m11). Having frequent and close interaction with relatives, however, does not compensate for missing meaningful relationships with non-related age peers, as expressed by the following Albanian woman: I have no other Albanian of my age to talk to, only with the family, who always says "We are here for you", but it is not enough (A0f2). Relationships outside the family are beneficial for spending time when family members are busy with other things, just for a chat or, as is the case with co-ethnic peers, to share memories and tell stories from the past: I sometimes feel lonely, I don't know anyone to spend my spare time with, sharing thoughts and experiences (M1f12). In addition, close friendships with non-related age peers are important for talking about personal matters that people do not want or cannot express to their family, as echoed by an Albanian woman and a Moroccan man: I don't speak about loneliness with my husband. He wouldn't understand me. He always says "health is the most important thing, everything else has a remedy" (A1f11); Feelings of loneliness come to the fore when I am alone, when I have nobody to talk to about intimate things, someone close to my heart who gives me courage $(\mathrm{M} 1 \mathrm{~m} 13)$. This supports the argument from the literature on loneliness that different types of relationships serve different, more or less unique functions, and that these types of relationships are not or only barely interchangeable (Dykstra 1993; Weiss 1974).

In the remainder of this section we discuss the perceived underlying reasons for the participants' lack of meaningful relationships outside the family in particular and loneliness in general. By means of deduction, these are subsumed into one of the three groups of potential causal factors of loneliness as outlined in Section 2: late-life migration as an inter-individual cause, lack of personal resources as an intra-individual cause, and societal factors.

\section{Late-life migration}

Due to their migration move to Italy, loss of contact with stay-behind friends or limited opportunities to maintain contact with them is a common feature of our participants. The lack of new friends in the host country, who could at least partly compensate for old friends, is most prominent among the zero generation. Compared to the first generation, they have had less time to build up a social network beyond their family. Moreover, because of their shorter stay in Italy, their social situation in Albania/Morocco is more etched in their memory than that of their first-generation counterparts. Elderly newcomers seem to compare more their current social network with the one they had in the home country, and to feel the loss more due to migration. The following two quotes are illustrative: Here I miss friendships, here I can always have roast beef, but if I eat it alone, it is not right. I wish I had contact with other people, it would be better if I knew peers for my spare time. The neighbours or other people I have [in Morocco], I know them all my life. When I left the last time everyone came to say goodbye and we hugged each other, it was touching (M0f9); We miss friendship so much here [in Italy]. We know quite a few people here, but here relations are not like the ones in Albania (A0m7). 
Zero generation's children rarely act as a substitute for the lack of intimacy with co-ethnic peers in the host country. As described in the previous section, our participants do not like to share their feelings of loneliness with their offspring, mainly so their children would not worry. For the zero generation, however, loneliness is even more of an unspoken topic within the family. They do not like to talk about nostalgia, homesickness or other intimate feelings and sorrows with their offspring, as it seems that they feel obliged to be grateful to their children for bringing them to Italy (with better health care services, better economic conditions). And while they are severely dependent on their children, not just for practical matters but also for social ones (for details, see below), they do not want to burden them with their personal problems and feelings; they would feel guilty if they told their children that their life in Italy is not that satisfying. To a large extent they efface themselves, as painfully illustrated by two Albanian women:

I feel very lonely, although we [herself and her husband] live with our children and grandchildren. But I cannot talk to them about my feelings. I don't want to burden them, I don't want them to be worried. They are doing so much for us, so I prefer not to trouble them. I am happy when she [the daughter-in-law] talks to me about her feelings, her troubles and problems. However, we're not friends, I miss my same-age friends in Albania with whom I used to go out for coffee every day, I miss my home and intimacy, but I am happy to live with my family. (A0f10)

My dear, sure I know loneliness, it is tangled with my health and my nostalgia for home. Within my family, I can't talk about loneliness. They [children] would not understand and I would feel guilty. Actually let's stop talking about this, I wouldn't want my daughter-in-law to overhear me moaning about it. After all, she takes good care of me and she feeds me. It is not the food that I miss. Now yes, I do feel lonely, I told you. (A0f16)

\section{Lack of personal resources}

Within the second group - lack of personal resources - there are three main causes acting as barriers to social contact outside the family: (a) lack of Italian language proficiency; (b) lack of economic resources; and (c) lack of free time. Lack of Italian language proficiency seems to be one of the most important factors, as it makes interaction with neighbours difficult and sometimes even impossible, as stated by this Moroccan lady: I don't have contact with my neighbours, just "hi". At the beginning the landlady living opposite us told one of my grandchildren that the hallway smells because we use many spices to cook. The next day I cooked something special and brought her a portion. She didn't say anything but I know she liked it. So every time I cook something special I bring her a portion. We gesticulate to communicate (M1f7). Language in particular acts as a wedge for the zero generation. Because they arrived relatively recently in Italy and were already older, it is very difficult for them to learn Italian: The problem here [Italy] is language, communicating is important for everyone, loneliness eats away at me (A0m9). Not having contact with their neighbours is quite shocking for those who were used to having a wide network of social relations in the home country: In the morning my neighbours [in Albania] would visit me and we'd have coffee and spend time talking about our sons around the world. Where could I go here? Whom can I speak to? (A0f16). Some of them do not feel the need to learn Italian, as they are surrounded by their family most of the time: I have little contact with Italian people and I'm almost always with my relatives, so I don't need to speak Italian (M0f5). These participants rely entirely on their children and grandchildren for any activity that requires using the Italian language, from visits to the doctor to shopping. Accordingly, while the younger generations attend school or go to work, they are 'like a mouse in a trap at home' (A0f10).

It is worthy to note that sometimes language also acts as a barrier within the family sphere, particularly in families with Italian children-in-law and with grandchildren. For 
Albanian and Moroccan families, marriage represents a very important event that not only involves the young couple but also links the families of the spouses through enduring ties. Migration has in many cases interrupted this tradition, as the younger generation lives and assimilates in Italy; this weakens the guarantee that they will find a spouse from the same ethnic background. Language barriers with grandchildren mainly occur among the Albanian zero generation. While language preservation seems to be an unquestionable topic in Moroccan migrant families, regardless of inter- or intra-ethnic marriages, children of firstgeneration Albanian migrants usually speak Italian and are not keen on learning Albanian. In these cases grandparents lose one of the most important acknowledged roles within the family, that of contributing with their knowledge to the education of the younger generation and preserving elements of Albanian language and culture within the family.

Lack of economic resources is another factor within the second group of causal factors of loneliness. Sufficient income is necessary to meet people and engage in outdoor social activities (money for a cup of coffee, bus fare, social visits, etc.). The majority of our participants are not wealthy and the economic crisis, which has been quite severe in Italy, has exacerbated their financial situation: I know a Moroccan family in [place in Ancona province, $46 \mathrm{~km}$ from residence] that we hang out with every now and then. We went to them, they came to us. But not anymore, because I can't drive, I couldn't pay the car insurance, I'm unemployed since July last year, I was fired because of the crisis (M1m2).

Although the fragile economic situation affects the whole family, especially male participants stress the lack of financial means. For the first generation this relates to the fact that the economic crisis not only resulted in mass layoffs among men but has also changed gender relations. The continuing economic downturn has caused a drop in demand of labour in traditionally male migrant-specific sectors such as construction, while jobs in the femaledominated care sector have increased due to the rapid ageing of the Italian population (Fondazione Leone Moressa 2013). As a result, our female participants have either always continued working despite the economic crisis or, especially among Moroccan women, started working after their husband's dismissal, becoming the family's main breadwinner. Such situations have generated confusion about family roles, frustration and low self-esteem among male migrants. They feel uncomfortable being financially dependent on their wives, and perceive unemployment as a threat to their pivotal role within the family. Most Moroccans regret not having migrated to France at an earlier stage in their lives, where they believe it is easier to find a job and better living conditions because of a strong Moroccan community. Zero-generation elders, on the other hand, are highly dependent financially on the incomes of their children, who usually are not well-off. They receive a very small amount of pension from their country of origin and no pension at all in Italy, or at best a small social allowance (about EUR 450) after ten years of legal and continuous residence. Financial dependency on their children discourages them from going out: They [children] are already making a lot of sacrifices for us, they have their own financial problems, we don't want to ask them money for a bus ticket to go downtown. Having friends means going to a bar, taking a coffee, one time you pay for them and next time they pay for you. But without money what can we do? Where can we go? We don't have any distraction and the day is long. Loneliness is like a nasty disease that eats us up little by little, day by day (A0f10).

Lack of free time is the last cause in the group of personal resources. Those men still on the labour market complain about the long working hours: We always work [in Italy] from morning to evening, there is no time for anything else. In Albania life was organised differently. We worked until 3 PM and then the afternoon was free, we could walk, meet friends and relatives, have a social life. This is my solitude, I feel bad. I miss the pleasure of the day after working. Even though I was tired, after work I had time and opportunity to meet people, it was a pleasure (A1m4). The impact on loneliness of having no time for oneself is 
less straightforward for women. In general, our female participants stress household and caregiving duties as causes for their narrow social circle. Typically being the kinkeeper of the family, they are often too busy with household chores, looking after grandchildren and taking care of ill family members to build a social network outside the immediate family context. This is even more the case for zero-generation women, which is not surprising as caregiving is their main motive for moving to Italy: Because I take care of my grandson, I don't have much time to know other people. My only distraction is to have coffee at a friend's house. During the week we have different schedules so we can meet only on weekends, but even then there is always something to do at home: relatives who come visit, lunches, dinners, and so on, and then the same routine starts again (A0f19). Somewhat paradoxically, for some women fulfilling the kinkeeper role is a way to avoid severe loneliness. By being constantly busy with home chores they often lack the time to think about loneliness or other problems: I have eight children and fifteen grandchildren. I don't have time to go out. I don't have time to think about me, I'm always busy. I never stop cooking, washing and looking after my youngest grandchildren. My house is always full of people. It's always very noisy. When my grandchildren come back from school they first stop here, eat here, rest here, and then go to their home (M1f7).

\section{$\underline{\text { Societal barriers }}$}

Apart from late-life migration and a lack of personal resources, there are several societal factors that hinder our participants from having a satisfying social life outside the family. The most oft-cited environmental causes are: (a) discrimination; (b) the individualistic, workoriented culture of Italy; (c) a small pool of like-minded peers; (d) lack of social meeting places and centres for migrants; and (e) the hilly nature of the Marche region.

When participants were asked about integration into Italian society, stories of personal experiences of discrimination were often recalled by the first generation. Both Moroccans and Albanians stress that discrimination have made it difficult to make friends among Italian locals, though the former also acknowledge the social wound of their dual identity, as highlighted by the following quote: We, Moroccans, say " a crow that tries to walk like a pigeon ends up walking like neither a crow nor a pigeon". This is the problem with immigration. The duality of being a bit Moroccan and a bit Italian sometimes hurts, you are neither Italian nor Moroccan and this causes problems of adaptation and discrimination (M1m6). For Albanians, discrimination also has a negative impact on their co-ethnic network. Although Albanians are in many respects more similar to the Italian population than Moroccans, and consider themselves as such (King and Mai 2009), they are one of the groups most rejected and stereotyped by the Italian media (King and Mai 2008). Because of the strong exposure to discrimination, our first-generation Albanians not only tried to assimilate into Italian society: as their assimilation did not result in the disappearance of prejudice, they also adopted another overriding coping strategy, that of social mimesis (Romania 2004), making themselves invisible in public spaces by hiding their identity. Their narratives show, for example, that they did not practice religion in Albania but nonetheless baptized their children and let them study the Catholic religion like their Italian peers in order to be considered members of the mainstream population. In social terms, as found in previous studies (King and Mai 2009), they avoid speaking Albanian in public spaces and interacting with Albanian fellows who are not part of their kinship and close-friends circle; over time, this results in a narrow network of Albanian friends: There was too much discrimination and stigmatization in Italy, being Albanian was almost something to be guilty about, so Albanians have learned to live in silence and be invisible and I don't mix with the Albanian community (A1m6). The strategy to avoid anti-Albanian sentiments has also had an impact on zerogeneration Albanians' social life: There are other Albanians living in the neighbourhood but 
we do not know them. Even my daughter who lives here for 20 years does not have contact with other Albanians (A0f2). Their migrant children discourage and in some cases even forbid them from interacting with other Albanians.

The second societal factor regards the individualistic, work-oriented culture of Italian society, which is completely different from their customs and expectations. They come from cultural settings where togetherness and frequent social contacts are social values. Neighbours are friends and houses are places of social contact and interactions: In Albania the front door is always open, so the neighbours can come in and out whenever they want without having to knock on the door. We hang together on the landing, chatting and having coffee, the children grow up together, neighbours were our closest friends (A1m6). In Italy houses are perceived as 'prisons, graveyards' and people as 'indifferent and cold'. Our participants further complain about the high work ethic and the fast-paced society in Italy. There is little time for socialising; colleagues and neighbours do not have so much time for a social talk, children do not have time to go out with their parents. With regard to the latter, especially the Albanian zero generation complains about the spare time of their own children and grandchildren. They have made a lot of sacrifices by looking after and taking care of the grandchildren to enable their offspring to integrate into the host countries. The flipside is losing the pivotal role they traditionally had in Albania and the young generation not meeting their culturally embedded expectations. They often feel neglected by their busy offspring; it is up to their children whether they will go out for a walk or shopping on the weekend: We need our children to introduce us to other people but they are busy. They're always at work and then when they come home they do chores or go out (A0f2).

A third societal factor that makes it difficult for our participants to 'upgrade' their nonkin network is the small pool of like-minded peers. This is especially true for high-educated Albanians. As the majority of Albanian migrants in Italy have a low educational level (ISTAT 2008), they have difficulties finding co-ethnic peers with similar backgrounds and interests 'I am surrounded by Albanians I did not choose, with whom we have nothing to share' (A1m4) - and often prefer no contact with peers instead of 'superficial relations': Another problem of immigration is that you create friendships, but these are random friendships because you don't have much choice, they are superficial relations. I cannot find people I'm completely compatible with. A couple of times I tried seeing certain people, but then I gave up because I didn't find them interesting. Sometimes I feel depressed, I ask myself questions and I read a lot, it is a solution but it's not satisfying. This lack of choice is tough, the friendships you had in Albania are the result of choices made by your family and afterwards made by you at school and in college, but here in Italy you see people just because they speak the same language (A1f12).

Lack of ethnic-specific meeting places is another societal factor that complicates socialisation outside the family. In this respect, Moroccan males miss places like teahouses and mosques. In their home country, mosques are around every corner and within easy walking distance. Moreover, the mosque is always open, which makes it an important place not only for praying but also for chatting, unlike Italy where the mosque is only open on Fridays for praying and on Saturdays for learning Arabic: Here the mosque functions only on Fridays, and it's sometimes open in the evening. In Morocco the mosque is always open, both before and after prayers, you don't go just to pray but also to meet people, a sort of social centre with a religious formula (M1m3). For female migrants there is a total absence of special places and social activities, as witnessed by this Albanian woman: There is one meeting place, [name of the meeting place], but it's not good as a meeting point, it offers coffee, grappa, is a bit macho, but it's not a cultural point (A1f12).

Related to some extent to the fourth societal factor is the hilly nature of the Marche region, which makes it difficult to walk to places; in this sense, having a car to get around is 
not a luxury. Zero-generation participants are the most affected by this geography, as none of them have a driver's license and in their home country they were used to manage everything by foot (shopping, going to the mosque, meeting friends): Going to the city centre is tiring for us. He [the husband] manages it, but I get tired. It's all uphill here. We're not used to it (M0f5). Since public transport is rather limited and no or few meeting places are close-by, they are highly dependent on their offspring to go out. To avoid being a burden they rarely ask their children or grandchildren to bring them to social places, so they often remain trapped at home: Here I cannot exchange two words with anybody. It would be a pleasure to meet other Albanians, it would feel good, but we haven't yet met other Albanians who live around here. We need our sons or grandchildren to take us to the park [where other older Albanians go], we can't go out on our own. Here it is difficult to get around without a car, it's all uphill and downhill and we're not able to take long walks (A0f2). Lacking a driver's license also holds for the majority of first-generation females, making them highly dependent on the younger generation or their male partners. Especially for Albanian women, not having a driver's license after many years in Italy and devoting their time and energy to their family becomes a reason for marital arguments, as witnessed by the voice of this first-generation Albanian woman: I haven't made my voice heard [within the family], I've let others decide. I've taken little charge of my life. I've let my husband decide (A1f8).

\section{Conclusion and Discussion}

This paper presents the first study on older migrants' social wellbeing in Italy. Lived experiences and perceived causes of loneliness were explored by in-depth interviews with 19 Albanian and 15 Moroccan migrants of the zero and first generations aged 50 and older living in the Marche region. The first generation emigrated to Italy at a young age to work (mainly men) or to follow their partners (mainly women). The zero generation came at a relatively old age to Italy to be reunited with their migrant children, ensuring intergenerational support (King et al. 2014).

The narratives show that, strictly speaking, almost none of the participants are socially isolated: they are embedded in the family and are overall satisfied with the relationships they have with family members. Yet, they (sometimes) do experience feelings of loneliness, although they are not likely to share and discuss these feelings with their children as they do not want them to worry (first and zero generation) or feel guilty (in case of the zero generation), or with others, out of shame and fear of being seen as weak (mainly men). The root of their loneliness largely relates to a lack of satisfying relationships outside the family and in particular with co-ethnic peers. A non-kin social network in Italy is wished to compensate for the loss or limited contact they are able to have with their old friends and neighbours in their country of origin. Get-togethers with non-relatives are more than enjoyable ways to have a chat, retrieve memories of the past, or spend time when family members are busy; it also gives them the opportunity to talk about intimate matters they cannot or do not want to share with family members, supporting the argument of loneliness scholars that different types of relationships serve different functions and fulfil different needs so that they are not or are only barely interchangeable components of the social network (Dykstra 1993; Weiss 1974).

The participants' perceived underlying reasons for the lack of satisfying relationships outside the family are diverse and can be subsumed into one of the three groups of potential causal factors of loneliness - inter-individual, intra-individual and societal causes - that are usually identified in the literature. In the group of inter-individual causes, of the transitions in life that are usually accompanied with a loss or reduction of contact with people, late-life migration is the most prominent; general major late-life events such as widowhood or severe 
health deterioration, on the other hand, are not yet at stake, given participants' relatively young age. In the group of intra-individual causes, lack of Italian language proficiency, economic resources and free time are the main personal factors why our participants have less contact with non-relatives than they would like. In the group of societal causes, especially discrimination, the individualistic and work-oriented culture of Italy, the small pool of likeminded peers, a dearth of migrant-specific social meeting places, and the hilly nature of the Marche region are perceived as societal factors that act as barriers to social contact outside the family.

Given that some of these causes are interrelated and likely to be cumulative in their effects, our zero-generation participants - almost all of Albanian origin - seem to be the ones with the most severe feelings of loneliness. They left their home country to be reunited with their migrant children and to help them with household chores and childcare. In Italy they become severely dependent on their children, socially speaking. Lack of Italian language proficiency, economic resources and free time prevent them from engaging in outdoor social activities and establishing new contacts beyond the family borders. In addition, opportunities to meet co-ethnic peers in the family setting are limited due to children's busy working life and, as a side-effect of being discriminated, their reluctance to have contacts with other Albanians outside the kinship and close-friends circle. Moreover, because of their shorter stay in Italy and the 'fresh memories' of intimate relationships with friends and neighbours in their home country, it is likely that they evaluate the deficiencies in the current network of nonrelatives more negatively than their first-generation counterparts do.

The small sample size, an unequal distribution of zero- and first-generation migrants, and the use of a non-representative sample of only two ethnic groups do not allow us to draw any generalisable conclusions from the findings. Further study with a larger heterogeneous random sample of older migrants is recommended. Being restricted to the Marche region in Italy, the study is also limited in its geographical scope. Cross-regional and cross-national comparative research needs to be conducted to know more about the robustness and nature of the migrant-loneliness link in different contextual settings. As described in the introduction, social integration of migrants is not a topic that is high on the political agenda in Italy, and older migrants are rarely the target group of local authorities and non-state actors. Moreover, the Marche region is characterised by a number of aspects that hinder social integration, e.g. a widespread settlement of the native and migrant populations, a large hilly area and insufficient public transport services. These case-specific circumstances might have coloured our findings, although they point in the same direction as the findings of the few other previous qualitative studies on the same topic among other ethnic groups and in different contextual settings (Choudhry 2001; Ip, Lui and Chui 2007; Lee 2007; Treas and Mazumdar 2002).

Despite its limitations, our study does offer important insights into a rather neglected topic related to the intersection of ageing and migration and the social vulnerability that may occur in migrants' later life. Loneliness is both a personal and a societal issue; it is likely to jeopardise individuals' wellbeing in its psychological (Cacioppo et al. 2006) and physical dimensions (Cacioppo et al. 2002; Hawkley and Cacioppo 2010; Routasalo and Pitkala 2003), and to be a large financial burden on society. We hope that our work will inspire the Italian government and non-governmental organisations (e.g. professionals in the healthcare and social sectors) to find ways in which they can be helpful to ageing migrants by reducing or even better - preventing loneliness. Options to explore in this respect are providing language lessons, low-cost transport facilities and social meeting places for older migrants, opening the doors of third-age universities to migrant seniors, expanding the functions of mosques, and setting up home visits (perhaps with a key role for female migrants working in the healthcare 
or social care sector) to those older migrants who have a very limited social network outside the family.

\section{Acknowledgements}

Eralba Cela's research is part of the 'Ageing, Migration and Health in Multi-ethnic Societies' post doctoral project, co-funded by the Department of Economics and Social Sciences of the University of Ancona and the 'AdriHealthMob' project within the IPA Adriatic Cross Border Cooperation Programme (2007-2013). Tineke Fokkema's research is part of the 'Families in Context' project, funded by an Advanced Investigator Grant of the European Research Council (ERC, 324211). We would like to express our sincerest thanks to the two anonymous reviewers for their highly constructive comments and suggestions, which have significantly improved the paper from its earlier version. Our special thanks also go to Nina Conkova, member of the Families in Context project, for her tireless support and precious comments during the final revision process. 


\section{References}

Ambrosetti, E., Cela, E. and Fokkema, T. 2013. The differential impact of the legal status of migrants in Italy on transnationalism: just a matter of time and integration? Journal of Mediterranean Studies, 22, 1, 33-60.

Arjouch, K.J. 2005. Arab-American immigrant elders' views about social support. Ageing \& Society, 25, 5, 655-73.

Balbo, M. 2015. Migrazioni e piccoli comuni [Migration and Small Municipalities]. FrancoAngeli, Milano.

Barban, N. and White, M.J. 2011. Immigrants' children's transition to secondary school in Italy. International Migration Review, 45, 3, 702-26.

Boccagni, P. and Ambrosini, M. 2012. Cercando il benessere nelle migrazioni. L'esperienza delle assistenti familiari straniere in Trentino [Searching for Well-being in Migration. The Experience of Foreign Domestic Helpers in Trentino]. FrancoAngeli, Milano.

Bolzman, C., Fibbi, R. and Vial, M. 2001. La famille: une source de légitimité pour les immigrés après la retraite. Revue Européenne des Migrations Internationales, 17, 1, 55-78.

Bolzman, C., Fibbi, R. and Vial, M. 2006. What to do after retirement? Elderly migrants and the question of return. Journal of Ethnic and Migration Studies, 32, 8, 1359-75.

Bolzman, C., Poncioni-Derigo, R., Vial, M. and Fibbi, R. 2004. Older labour migrants' well-being in Europe: the case of Switzerland. Ageing and Society, 24, 3, 411-29.

Bonifazi, C., Heins, F., Strozza, S. and Vitiello, M. 2009. The Italian transition from emigration to immigration country. IRPPS Working Papers, 24, 1-104.

Cacioppo, J.T., Hawkley, L.C., Crawford, L.E., Ernst, J.M., Burleson, M.H., Kowalewski, R.B., Malarkey, W.B., van Cauter, E. and Berntson, G.G. 2002. Loneliness and health: potential mechanisms. Psychosomatic Medicine, 64, 3, 407-17.

Cacioppo, J.T., Hughes, M.E., Waite, L.J., Hawkley, C.L. and Thisted, R.A. 2006. Loneliness as a specific risk factor for depressive symptoms: cross-sectional and longitudinal analyses. Psychology and Ageing, 21, 1, 140-51.

Caneva, E. 2014. The integration of migrants in Italy: an overview of policy instruments and actors. INTERACT Research Report 2014/05. European University Institute, Robert Schuman Centre for Advanced Studies, San Domenico di Fiesole (FI).

Caponio, T. 2002. Policy networks e immigrazione. Il caso delle politiche sociali a Milano e a Napoli [Policy networks and immigration. The case of social policies in Milan and Naples]. In Colombo, A. and Sciortino, G. (eds), Stranieri in Italia. Assimilati ed esclusi ? [Foreigners in Italy. Assimilated and Excluded?]. Il Mulino, Bologna.

Caponio, T. 2006. Città italiane e immigrazione. Discorso pubblico e politiche a Milano, Bologna e Napoli [Italian Cities and Immigration. Public Discourse and Policies in Milan, Bologna and Naples]. Il Mulino, Bologna.

Caponio, T. 2010. Grassroots multiculturalism in Italy: Milan, Bologna and Naples compared. In: Caponio, T. and Borkert, M. (eds), The Local Dimension of Migration Policymaking. University Press, Amsterdam, 57-84.

Caponio, T. and Zincone, G. 2011 WP2 - The national policy frame for the Integration of Newcomers in Italy. Research paper for the PROSINT (Promoting Sustainable Policies for Integration) project. Vienna.

Cela, E., Fokkema, T. and Ambrosetti, E. 2013. Variation in transnationalism among Eastern European migrants in Italy: the role of duration of residence and integration. Southeast European and Black Sea Studies, 13, 2, 195-209.

Chiatti, C., Di Rosa, M., Melchiorre, M.G., Manzoli, L., Rimland, J.M. and Lamura, G. 2013. Migrant care workers as protective factor against caregiver burden: results from a longitudinal analysis of the EUROFAMCARE study in Italy. Aging \& Mental Health, 17, 5, 609-14.

Choudhry, U.K. 2001. Uprooting and resettlement experiences of South Asian immigrant women. Western Journal of Nursing Research, 23, 4, 376-93.

Ciobanu, R.O. 2012. Ageing migrants in Portugal: methodological discussion and empirical evidence. Revista Migrações - Número Temático Imigração e Envelhecimento Ativo, April 2012, 10, 83-102. 
Cornwell, E.Y. and Waite, L.J. 2009. Measuring social isolation among older adults using multiple indicators from the NSHAP study. The Journals of Gerontology, Series B, Psychological Sciences and Social Sciences, 64, 1, 38-46.

Dalla Zuanna, G., Farina, P. and Strozza, S. 2009. Nuovi italiani. I giovani immigrati cambieranno il nostro paese? [New Italians. Will Young Immigrants Change our Country?]. Il Mulino, Bologna.

de Coulon, A. and Wolff, F.-C. 2010. Location intentions of immigrants at retirement: stay/return or go 'back and forth'? Applied Economics, 42, 26, 3319-33.

de Haas, H. and Fokkema, T, 2010. Intra-household conflicts in migration decisionmaking: return and pendulum migration in Morocco. Population and Development Review, 36, 3, 541-56.

de Jong Gierveld, J. 1984. Eenzaamheid: een meersporig onderzoek [Loneliness: A Multimethod Approach]. Van Loghum Slaterus, Deventer.

de Jong Gierveld, J. 1998. A review of loneliness: concept and definitions, determinants and consequences. Reviews in Clinical Gerontology, 8, 1, 73-80.

de Jong Gierveld, J., Broese van Groenou, M.I., Hoogendoorn, A.W. and Smit, J.H. 2009. Quality of marriages in later life and emotional and social loneliness. Journal of Gerontology: Social Sciences, 64B, 4, S497-506.

de Jong Gierveld, J., van Tilburg, T. and Dykstra, P.A. 2006. Loneliness and social isolation. In Vangelisti, A. and Perlman, D. (eds), The Cambridge Handbook of Personal Relationships. Cambridge University Press, New York, 485-500.

de Valk, H.A.G. and Schans, D. 2008. 'They ought to do this for their parents': perceptions of filial obligations among immigrant and Dutch older people. Ageing \& Society, 28, 1, 49-66.

den Draak, M. and de Klerk, M. 2011. Oudere migranten: kennis en kennislacunes [Old Migrants: Knowledge and Knowledge Gaps]. Sociaal en Cultureel Planbureau, Den Haag.

Di Rosa, M., Melchiorre, M.G., Lucchetti, M. and Lamura, G. 2012. The impact of migrant work in the elder care sector: recent trends and empirical evidence in Italy. European Journal of Social Work, 15, 1, 9-27.

Dykstra, P.A. 1993. The differential availability of relationships and the provision and effectiveness of support to older adults. Journal of Social and Personal Relationships, 10, 3, 355-70.

Dykstra, P.A. 2009. Older adult loneliness: myths and realities. European Journal of Ageing, 6, 2, 91100.

Dykstra, P.A. and de Jong Gierveld, J. 2004. Gender and marital-history differences in emotional and social loneliness among Dutch older adults. Canadian Journal of Aging, 23, 2, 141-55.

Dykstra, P.A. and Fokkema, T. 2007. Social and emotional loneliness among divorced and married men and women: comparing the deficit and cognitive perspectives. Basic and Applied Social Psychology, 29, 1, 1-12.

Ebrahim, S. 1996. Caring for older people: ethnic elders. British Medical Journal, 313, 7057, 610-13.

Finotelli, C. and Sciortino, G. 2009. The importance of being southern: the making of policies of immigration control in Italy. European Journal of Migration and Law, 11, 2, 119-38.

Fokkema, T., Cela, E. and Witter, Y. 2016. Pendular migration of older adults: misconceptions and nuances. In Horn, V. and Schweppe, C. (eds), Transnational Aging: Current Insights and Future Challenges. Routledge, New York, 141-61.

Fokkema, T. and de Haas, H. 2011. Pre- and post-migration determinants of socio-cultural integration of African immigrants in Italy and Spain. International Migration. DOI: 10.1111/j.14682435.2011.00687.x

Fokkema, T., de Jong Gierveld, J. and Dykstra, P.A. 2012. Cross-national differences in older adult loneliness. The Journal of Psychology, 146, 1-2, 201-28.

Fokkema, T. and Naderi, R. 2013. Differences in late-life loneliness: a comparison between Turkish and native-born older adults in Germany. European Journal of Ageing, 10, 4, 289-300.

Fondazione Leone Moressa 2013. Rapporto annuale sull'economia dell'immigrazione. Edizione 2013 [Annual Report on Immigration Economics. 2013 Edition]. Il Mulino, Bologna.

Gabrielli, G., Paterno, A. and Dalla Zuanna, G. 2013. Just a matter of time? The ways in which the children of immigrants become similar (or not) to Italians. Journal of Ethnic and Migration Studies, 39, 9, 1403-23.

Ganga, D. 2006. From potential returnees into settlers: Nottingham's older Italians. Journal of Ethnic and Migration Studies, 32, 8, 1395-1413. 
Golini, A. and Moretti, E. (eds) 2011. Is immigration the answer to the ageing problem in the lowestlow fertility countries? Genus, 67, 3, 31-5.

Guest, G.S., MacQueen, K.M. and Namey, E.E. 2012. Applied Thematic Analysis. Sage Publications, Thousand Oaks, California.

Guiaux, M. 2010. Social Adjustment to Widowhood: Changes in Personal Relationships and Loneliness before and after Partner Loss. PhD Thesis, VU University, Amsterdam.

Hawkley, L.C. and Cacioppo, J.T. 2010. Loneliness matters: a theoretical and empirical review of consequences and mechanisms. Annals of Behavioral Medicine, 40, 2, 218-27.

Hawkley, L.C., Hughes, M.E., Waite, L.J., Masi, C.M., Thisted, R.A. and Cacioppo, J.T. 2008. From social structural factors to perceptions of relationship quality and loneliness: the Chicago health, aging, and social relations study. Journal of Gerontology, Social Sciences, 63B, 6, S375-84.

Ip, D., Lui, C.W. and Chui, W.H. 2007. Veiled entrapment: a study of social isolation of older Chinese migrants in Brisbane, Queensland. Ageing \& Society, 27, 5, 719-38.

ISTAT - Italian institute of Statistics - www.istat.it

ISTAT 2008. Gli stranieri nel mercato del lavoro. I dati della rilevazione sulle forze di lavoro in un'ottica individuale e familiare [Foreigners in the labour market. Data from the Labour Force Survey from an individual and family perspective], Argomenti N. 36. Available online at http://www3.istat.it/dati/catalogo/20090109 00/stranieri nel mercato lavoro.pdf

ISTAT 2013, data available at http://demo.istat.it/str2013/index.html.

Jylhä, M. 2004. Old age and loneliness: cross-sectional and longitudinal analyses in the Tampere longitudinal study on aging. Canadian Journal on Aging, 23, 2, 157-68.

King, R., Cela, E., Fokkema, T. and Vullnetari, J. 2014. The migration and wellbeing of the zero generation: transgenerational care, grandparenting and loneliness amongst Albanian older people. Population, Space and Place, 20, 8, 728-38.

King, R., Lazaridis, G. and Tsardanidis, C. (ed.) 2000. Eldorado or Fortress? Migration in Southern Europe. Macmillan, London.

King, R. and Mai, N. 2008. Out of Albania. Bergham Books, Oxford/New York.

King, R. and Mai, N. 2009. Italophilia meets Albanophobia: paradoxes of asymmetric assimilation and identity processes among Albanian immigrants in Italy. Ethnic and Racial Studies, 32, 1, 117-38.

Kuyper, L. and Fokkema, T. 2010. Loneliness among older lesbian, gay, and bisexual adults: the role of minority stress. Archives of Sexual Behavior, 39, 5, 1171-80.

Lan, P.C. 2002. Subcontracting filial piety: elder care in ethnic Chinese immigrant families in California. Journal of Family Issues, 23, 7, 812-35.

Lau, S. and Gruen, G.E. 1992. The social stigma of loneliness: effect of target person's and perceiver's sex. Personality and Social Psychology Bulletin, 18, 2, 182-9.

Lauder, W., Sharkey, S. and Mummery, K. 2004. A community survey of loneliness. Journal of Advanced Nursing, 46, 1, 88-94.

Lee, Y.-M. 2007. The immigration experience among elderly Korean immigrants. Journal of Psychiatric and Mental Health Nursing, 14, 4, 403-10.

Moretti, E. 2011. L'immigrazione è una risposta all'invecchiamento della popolazione? Il caso delle Marche [Is immigration the solution to population ageing? The case of the Marche region]. In: Unioncamere Marche and Università Politecnica delle Marche (eds.), Le Marche oltre la crisi. Quale possibile percorso di sviluppo. Un approccio integrato per il futuro [The Marche Beyond the Crisis. Possible Development Paths. An Integrated Approach]. FrancoAngeli, Milano, 17-25.

Moretti, E. and Cela, E. 2008. L'immigrazione albanese in Italia: 1990-2005 [Albanian migration in Italy: 1990-2005]. In Di Comite, L., Garavello, O. and Galizia, F. (eds), Sviluppo Demografico ed Economico del Mediterraneo [Demographic and Economic Development in the Mediterranean]. Cacucci, Bari, 351-74.

Morettini, G. and Socci, M. 2012. Città multietniche. Immigrazione e mutamento sociale nei sistemi urbani della terza Italia [Multiethnic cities. Immigration and social change in the urban systems of the Third Italy]. In: Calafati, A.G. (ed.), Le citta dellà terza Italia. Evoluzione strutturale e sviluppo economico. [The Cities of the Third Italy. Structural Evolution and Economic Development]. FrancoAngeli, Milano, 151-214.

Nachega, J.B., Morroni, C., Zuniga, J.M., Shere, R., Beyrer, C., Solomon, S., Schechter, M. and Rockstroh, J. 2012. HIV-related stigma, isolation, discrimination, and serostatus disclosure: a 
global survey of $2035 \mathrm{HIV}$-infected adults. Journal of the International Association of Providers of AIDS Care, 11, 3, 172-8.

Nedelcu, M. 2009. La génération zéro: du sédentaire a l'acteur circulant. Effects de mobilité sur la génération des parents des migrants roumains hautement qualifies à Toronto a l'ère du numérique. In Cortes, G. and Faret, L. (eds), Les Circulations Transnationales: Lire les Turbulences Migratoires Contemporaines. Armand Colin, Paris, 187-98.

Oberg, K. 1960. Cultural shock: adjustment to new cultural environments. Practical Anthropology, 7, $177-82$.

Pasquinelli, S. and Rusmini, G. 2010. La regolarizzazione delle Badanti [The status legalisation of migrant care workers]. In Network Non Autosufficienza (ed.), L'assistenza Agli Anziani Non Autosufficienti in Italia - Rapporto 2010 [The Long-term Care System for the Elderly in Italy Report 2010]. Maggioli Editore, Santarcangelo di Romagna.

Percival, J. (ed.) 2013. Return Migration in Later Life: International Perspectives. Policy press University of Bristol, Bristol.

Peplau, L.A., Miceli, M. and Morasch, B. 1982. Loneliness and self-evaluation. In Peplau, L.A. and Perlman, D. (eds), Loneliness: A Sourcebook of Current Theory, Research, and Therapy. John Wiley, New York, 135-51.

Perlman, D. and Peplau, L.A. 1981. Toward a social psychology of loneliness. In Gilmour, R. and Duck, S. (eds), Personal Relationships 3: Personal Relationships in Disorder. Academic Press, London, 31-43.

Prieto-Flores, M.E., Forjaz, M.J., Fernandez-Mayoralas, G., Rojo-Perez, F. and Martinez-Martin, P. 2011. Factors associated with loneliness of noninstitutionalized and institutionalized older adults. Journal of Aging and Health, 23, 1, 177-94.

Rao, D.V., Warburton, J. and Bartlett, H. 2006. Health and social needs of older Australians from culturally and linguistically diverse backgrounds: issues and implications. Australasian Journal on Ageing, 25, 4, 174-9.

Romania, V. 2004. Farsi passare per Italiani: strategie di mimetismo sociale [Being Passed for Italians: Strategies of Social Mimesis]. Carocci, Rome.

Routasalo, P. and Pitkala, K.H. 2003. Loneliness among older people. Reviews in Clinical Gerontology,13, 4, 303-11.

Scharf, T. and de Jong Gierveld, J. 2008. Loneliness in urban neighbourhoods: an Anglo-Dutch comparison. European Journal of Ageing, 5, 2, 103-15.

Scharf, T., Phillipson, C. and Smith, A.E. 2005. Social exclusion of older people in deprived urban communities of England. European Journal of Ageing, 2, 2, 76-87.

Solé, C. 2004. Immigration policies in Southern Europe. Journal of Ethnic and Migration Studies, 30, 6, 1209-21.

Temple, B. and Young, A. 2004. Qualitative research and translation dilemmas. Qualitative Research, 4, 2, 161-78.

Treas, J. and Mazumdar, S. 2002. Older people in America's immigrant families: dilemmas of dependence, integration, and isolation. Journal of Aging Studies, 16, 3, 243-58.

Triandafyllidou, A. and Ambrosini, M. 2011. Irregular immigration control in Italy and Greece: strong fencing and weak gate-keeping serving the labour market. European Journal of Migration and Law, 13, 251-73.

Vertovec, S. 2006. The emergence of super-diversity in Britain. COMPAS (Centre on Migration, Policy And Society Working Paper), No. 25, University of Oxford.

Victor, C.R., Burholt, V. and Martin, W. 2012. Loneliness and ethnic minority elders in Great Britain: an exploratory study. Journal of Cross-Cultural Gerontology, 27, 1, 65-78.

Victor, C.R., Scambler, S.J., Bowling, A. and Bond, J. 2005. The prevalence of, and risk factors for, loneliness in later life: a survey of older people in Great Britain. Ageing \& Society, 25, 6, 357-76.

Warnes, A.M. and Williams, A. 2006. Older migrants in Europe: a new focus for migration studies. Journal of Ethnic and Migration Studies, 32, 8, 1257-81.

Weiss, R.S. 1974. The provisions of social relationships. In Rubin, Z. (ed.), Doing unto Others: Joining, Molding, Conforming, Helping, Loving. Prentice Hall, Englewood Cliffs, NJ, 17-26.

Wittenberg, M.T. and Reis, H.T. 1986. Loneliness, social skills, and social perception. Personality and Social Psychology Bulletin, 12, 1, 121-30. 
TABLE 1. Descriptive statistics of the participants

\begin{tabular}{|c|c|c|c|c|c|c|c|c|c|c|c|}
\hline ID & $\begin{array}{l}\text { Country of } \\
\text { origin }\end{array}$ & Age & Gender & Type of migrant & $\begin{array}{l}\text { Year of } \\
\text { arrival }\end{array}$ & Legal status & $\begin{array}{l}\text { Marital } \\
\text { status }\end{array}$ & $\begin{array}{l}\text { \# children } \\
\text { in Italy }\end{array}$ & $\begin{array}{l}\text { \# children } \\
\text { in origin } \\
\text { country }\end{array}$ & Education & Health \\
\hline A1m1 & Albania & 55 & $\mathrm{M}$ & labour & 1995 & long permit & married & 2 & 0 & secondary school & good \\
\hline A0f2 2 & Albania & 66 & $\mathrm{~F}$ & zero $\mathrm{G}$ & 1998 & long permit & married & 6 & 0 & primary school & good \\
\hline $\mathrm{A} 1 \mathrm{~m} 3$ & Albania & 60 & $\mathrm{M}$ & labour & 1991 & Italian citizenship & married & 3 & 0 & university & fair (injured at work) \\
\hline $\mathrm{A} 1 \mathrm{~m} 4$ & Albania & 60 & $\mathrm{M}$ & labour & 1991 & long permit & married & 2 & 0 & secondary school & good \\
\hline A1m5 & Albania & 58 & $\mathrm{M}$ & labour & 1991 & long permit & divorced & 2 & 0 & primary school & good \\
\hline A1m6 & Albania & 60 & M & labour & 1998 & long permit & married & 1 & 0 & secondary school & good \\
\hline $\mathrm{A} 0 \mathrm{~m} 7$ & Albania & 63 & $\mathrm{M}$ & zero $\mathrm{G}$ & 2001 & long permit & married & 2 & 0 & university & fair (injured at work) \\
\hline A1f8 & Albania & 55 & $\mathrm{~F}$ & family & 1992 & Italian citizenship & married & 3 & 0 & secondary school & good \\
\hline $\mathrm{A} 0 \mathrm{~m} 9$ & Albania & 84 & $\mathrm{M}$ & zero G & 2001 & long permit & married & 2 & 0 & secondary school & poor \\
\hline A0f 10 & Albania & 73 & $\mathrm{~F}$ & zero G & 2001 & long permit & married & 2 & 0 & secondary school & poor \\
\hline Alf11 & Albania & 55 & $\mathrm{~F}$ & labour & 1998 & long permit & married & 1 & 0 & university & good \\
\hline A1f12 & Albania & 59 & $\mathrm{~F}$ & labour & 1994 & Italian citizenship & married & 1 & 0 & university & good \\
\hline A0f 13 & Albania & 68 & $\mathrm{~F}$ & zero $\mathrm{G}$ & 2003 & long permit & married & 3 & 1 & primary school & good \\
\hline A1f14 & Albania & 60 & $\mathrm{~F}$ & family & 1991 & Italian citizenship & married & 4 & 0 & secondary school & good \\
\hline $\mathrm{A} 1 \mathrm{~m} 15$ & Albania & 55 & $\mathrm{M}$ & labour & 1999 & long permit & married & 3 & 0 & secondary school & good \\
\hline A0f16 & Albania & 83 & $\mathrm{~F}$ & zero $\mathrm{G}$ & 2012 & short permit & widowed & 4 & 2 & no education & poor \\
\hline A0f17 & Albania & 62 & $\mathrm{~F}$ & zero G & 1999 & long permit & married & 2 & 0 & secondary school & good \\
\hline $\mathrm{A} 0 \mathrm{~m} 18$ & Albania & 79 & M & zero $\mathrm{G}$ & 2006 & long permit & widowed & 2 & 0 & university & good \\
\hline A0f19 & Albania & 66 & $\mathrm{~F}$ & zero $\mathrm{G}$ & 1998 & long permit & married & 5 & 0 & primary school & good \\
\hline M1m1 & Morocco & 57 & $\mathrm{M}$ & labour & 1996 & long permit & married & 3 & 0 & secondary school & good \\
\hline $\mathrm{M} 1 \mathrm{~m} 2$ & Morocco & 53 & $\mathrm{M}$ & labour & 1998 & long permit & married & 1 & 0 & secondary school & good \\
\hline M1m3 & Morocco & 52 & $\mathrm{M}$ & labour & 1989 & Italian citizenship & married & 3 & 0 & secondary school & good \\
\hline $\mathrm{M} 1 \mathrm{~m} 4$ & Morocco & 52 & $\mathrm{M}$ & labour & 1990 & Italian citizenship & married & 2 & 0 & university & good \\
\hline M0f5 & Morocco & 68 & $\mathrm{~F}$ & zero G & 1988 & long permit & married & 3 & 4 & no education & poor \\
\hline M1m6 & Morocco & 58 & $\mathrm{M}$ & labour & 1985 & Italian citizenship & married & 4 & 0 & primary school & good \\
\hline M1f7 & Morocco & 70 & $\mathrm{~F}$ & family & 1989 & long permit & married & 8 & 1 & no education & poor \\
\hline M1m8 & Morocco & 78 & M & labour & 1985 & long permit & married & 8 & 1 & no education & poor \\
\hline M0f9 & Morocco & 62 & $\mathrm{~F}$ & zero $\mathrm{G}$ & 2008 & long permit & widowed & 2 & 2 & no education & good \\
\hline M1m10 & Morocco & 62 & $\mathrm{M}$ & labour & 1984 & Italian citizenship & married & 6 & 0 & primary school & fair (injured at work) \\
\hline M1m11 & Morocco & 60 & $\mathrm{M}$ & labour & 1985 & long permit & never married & 0 & 0 & primary school & poor \\
\hline M1f12 & Morocco & 55 & $\mathrm{~F}$ & family & 1997 & long permit & married & 3 & 0 & secondary school & good \\
\hline M1m13 & Morocco & 59 & $\mathrm{M}$ & labour & 1991 & long permit & married & 3 & 0 & secondary school & good \\
\hline M1m14 & Morocco & 52 & $\mathrm{M}$ & labour & 1987 & Italian citizenship & married & 3 & 0 & secondary school & good \\
\hline M1m15 & Morocco & 51 & $\mathrm{M}$ & labour & 1992 & Italian citizenship & married & 1 & 0 & secondary school & good \\
\hline
\end{tabular}




\section{Notes}

${ }^{i}$ At the Popdays organised by the Italian Association of Population Studies (AISP) in 2011, the opening session was dedicated to the topic 'Does Immigration represent the solution for an ageing population?'. For a detailed view of the papers presented, see Golini and Moretti (2011).

ii A short residence permit is the first legal document migrants obtain in Italy when staying for periods exceeding 3 months. Compared to the long residence permit, it is issued for shorter periods of time, depending on the migration motivation: up to 6 months (seasonal work), 1 year (vocational training course), or 2 years (selfemployment, open-ended employment and family reunification).

iii A long residence permit is a legal document issued for an indefinite period of time to people who have resided in Italy longer than five years and have a minimum income (equivalent to the amount of social security benefit). It does not give entitlement to citizenship, which non-EU citizens in Italy can request after 10 years of permanent residence.

iv The interview source is reported according to the following coding system: 'A' and ' $M$ ' represent Albanians and Moroccans, respectively, subsequently specifying type of migrant ( $0=$ zero generation, $1=$ first generation), gender of the interviewee $(\mathrm{m}=$ male, $\mathrm{f}=\mathrm{female})$, and interview number within the specific group. Thus A0f1 refers to the first interviewed Albanian, zero-generation woman. 